\title{
Pendidikan sains di sekolah menengah pertama perkotaan: Bagaimana sikap dan keaktifan belajar siswa terhadap sains?
}

\author{
Maison Maison, Dwi Agus Kurniawan *, Nur Ika Sandi Pratiwi \\ Universitas Jambi, Jl. Jambi-Ma. Bulian KM. 15, Muaro Jambi, Jambi 36122, Indonesia \\ * Coressponding Author. E-mail: dwiagus.k@unja.ac.id
}

Received: 14 June 2020; Revised: 6 July 2020; Accepted: 1 October 2020

\begin{abstract}
Abstrak: Abad ke-21 merupakan abad pengetahuan yang menghendaki segala aktivitas berbasis pada pengetahuan. Pada abad ke-21 ini sangat dibutuhkan keterampilan berpikir kritits, kreatif, kemampuan kolaboratif, metakognitif, kemampuan komunikasi, dan menguasai teknologi komunikasi. Selain itu, sikap dan keaktifan belajar merupakan hal penting yang harus dimiliki peserta didik dalam pembelajaran pada abad ke-21. Oleh karena itu penelitian ini dirancang untuk melihat bagaimana hubungan sikap dengan keaktifan belajar siswa terhadap mata pelajaran IPA. Penelitian ini adalah penelitian mix methods metode asosiatif jenis korelasional. Prosedur penelitian ini dimulai dengan menyebarkan angket, dokumetasi, dan wawancara. Pengambilan data angket data kuesioner diberikan kepada 147 siswa di SMPN 18 Kota Jambi. Dari data tersebut kemudian dilakukan analisis data yaitu pengkodean data, penyariangan data-data yang layak dan analisis dari data tersebut. Teknik analisis data menggunakan uji korelasional untuk mengetahui apakah terdapat hubungan antara sikap dan keaktifan belajar. Hasil dari penelitian ini terdapat hubungan yang positif antara sikap dan keaktifan siswa pada mata pelajaran IPA yang ditunjukkan dari hasil analisis pearson correlation sebesar 0.046 .
\end{abstract}

Kata Kunci: sikap, keaktifan belajar, IPA.

\section{Science education in urban secondary school: How attitude towards sciene and learning activity?}

\begin{abstract}
The $21^{\text {st }}$ century is the age of knowledge which requires all knowledge-based activities. In the $21^{\text {st }}$ century, critical thinking skills, creative skills, collaborative abilities, metacognitive skills, communication skills, and communication technology are needed. Besides, learning attitudes and activeness are important things that students must have in learning in the $21^{\text {st }}$ century. Therefore, this study was designed to see how the relationship between attitudes and student learning activeness in science subjects. This research is a mixed method research with an associative type of correlational method. This research procedure begins with distributing questionnaires, documentation, and interviews. Retrieving questionnaire data was given to 147 students at SMPN 18 Jambi City. From the data, data analysis was then carried out, namely data coding, filtering the appropriate data, and analyzing the data. The data analysis technique uses a correlational test to determine whether there is a relationship between attitudes and learning activeness. The results of this study showed a positive relationship between student attitudes and activeness in science subjects as indicated by the results of the Pearson correlation analysis of 0.046 .
\end{abstract}

Keywords: attitude, learning activity, natural science.

How to Cite: Maison, M., Kurniawan, D., \& Pratiwi, N. (2020). Pendidikan sains di sekolah menengah pertama perkotaan: Bagaimana sikap dan keaktifan belajar siswa terhadap sains?. Jurnal Inovasi Pendidikan IPA, 6(2), 135-145. doi:https://doi.org/10.21831/jipi.v6i2.32425

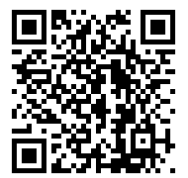

\section{PENDAHULUAN}

Pembelajaran Ilmu Pengetahuan Alam (IPA) di Sekolah Menengah Pertama dikenal juga sebagai pembelajaran sains. Pembelajaran IPA di sekolah menengah pertama merupakan konsep yang terpadu karena merupakan gabungan dari cabang ilmu sains di dalamnya (Kurniawan, Astalini, \& Anggraini, Evaluasi sikap siswa SMP terhadap IPA di Kabupaten Muaro Jambi, 2018). Ilmu Pengetahuan Alam (IPA) merupakan ilmu pengetahuan yang dapat diperoleh dengan menggunakan langkah-langkah kegiatan scientis misalnya observasi, pengukuran, merumuskan, meguji hipotesis, mengumpulkan data, 
bereksperimen dan prediksi deduksi untuk menghasilkan suatu penjelasan mengenai suatu gejala yang dapat dipercaya (Indriati, 2012); (Purbosari, 2016); (Utaminingsih, Rahayu, \& Andini, 2018); (Astuti, 2019). Melalui pembelajaran IPA siswa diharapkan dapat menggunakan keterampilan berpikir untuk menyelesaikan masalah dalam kehidupan sehari-hari, yang dapat dilakukan dengan membaca buku, menggunakan media digital untuk memperoleh informasi yang berkaitan dengan sains dan melakukan studi observasional tentang alam (Etherington, 2011); (Astalini, Pathoni, Kurniawan, \& Kurniawan, 2019); (Astalini \& Kurniawan, 2019); (Kurniawan, Astalini, Darmaji, \& Melsayanti, 2019). Pelajaran IPA di tingkat SMP memiliki kontribusi untuk menjadikan peserta didik mampu menjadi generasi yang memiliki sikap ilmiah dalam kehidupan maupun lingkungannya (Astalini, Kurniawan, Melsayanti, \& Destilanti, 2018).

Pada era abad 21 saat ini IPTEK berkembang sangat pesat, dimana segala sesuatu dapat diukur dengan menggunakan teknologi. Awal abad kedua puluh satu berlangsung industri 4.0 yang dicirikan dengan integrasi teknologi antara biologis, fisik dan digital spheres (Schwab, 2016). Sehingga sebagai peserta didik harus memahami perkembangan teknologi dan dapat menggunakannya dengan bijak agar dapat menyeimbangi perkembangan IPTEK. Sains (Fisika, Kimia, Biologi) memiliki kontribusi yang cukup besar dalam perkembangan teknologi, yakni sebagai ilmu dasar yang melandasi pengembangan teknologi (Sudarisman, 2015). Hal inilah yang menyatukan keduanya menjadi kesatuan yang dikenal sebagai Saintek/IPTEK. Oleh karenanya penguasaan sains menjadi sangat penting. Tempat kerja masa depan akan lebih banyak menekankan dalam keterampilan STEM (Ong, Chou, Yang, \& Lin, 2020). STEM merupakan singkatan dari Science, Technology, Engineering and Mathematics (Huang, Abdullah, \& Bunyamin, 2013). Oleh karena itu sangat penting untuk memicu minat siswa dalam pembelajaran sains dan mempromosikan sikap yang terkait dengan sains di antara para siswa. Hal ini sejalan dengan yang diugkapkan oleh (Lin, Cheng, Chang, \& Li, 2014), dimana sikap terhadap sains dan sikap ilmiah telah diakui memiliki peran penting dalam pembelajaran sains. Sikap terhadap pelajaran sains dan teknologi dapat mempengaruhi kesediaan untuk menggunakan keterampilan kognitif yang berkaitan dengan pelajaran, seperti mencari masalah dan memecahkan masalah dan hipotesis (USTA \& AKKANAT, 2015). Oleh sebab itu meningkatkan sikap siswa terhadap sains menjadi masalah penting bagi komunitas pendidik sains. Siswa yang bersikap negatif terhadap sains, misalnya tidak menyukai sains maka akan menyebabkan mereka gagal dalam sains, beberapa studi juga melaporkan bahwa sikap positif siswa terhadap sains berkorelasi tinggi dengan prestasi sains mereka (Adeyemo \& Babajide, 2012). Sikap positif terhadap sains menghasilkan pengalaman sains untuk akses masa depan karir siswa dan prestasi siswa.

Menyadari kompleksitas tantangan di masa depan, komisi bidang pendidikan UNESCO (Commision Education for the "21" Century) merekomendasikan 4 pilar pendidikan yang dapat dijadikan sebagai landasan pendidikan meliputi: (1) learning to know, yaitu belajar untuk mengetahui dengan cara menggali pengetahuan dari berbagai informasi; (2) learning to do, yaitu belajar untuk melakukan suatu tindakan atau mengemukakan ide-ide; (3) learning to be, yaitu belajar untuk mengenali diri sendiri dan beradaptasi dengn lingkungan; dan (4) learning to live together, yaitu belajar untuk menjalani hubungan bersama masyarakat yang saling bergantung, sehingga mampu bersaing secara sehat dan bekerja sama serta mmapu mengahargai orang lain. Selanjutnya, (Redhana, 2019), menyatakan bahwa tren pembelajaran sains abad 21 idealnya diarahkan pada 4 komponen yaitu: communication, collaboration, critical thinking \& problem solving, creativity \& innovation. Berdasarkan 4 komponen tersebut maka dalam pembelajaran diperlukan adanya keaktifan belajar peserta didik. Keaktifan belajar ditandai oleh adanya keterlibatan secara optimal, baik intelektual, emosi maupun fisik. Keaktifan belajar merupakan usaha yang dilakukan oleh guru pada waktu belajar mengajar, agar siswa melakukan kegiatan secara bebas baik secara jasmani maupun rohani, tidak takut berpendapat, memecahkan masalah sendiri, dan siswa selalu termotivasi untuk berpendapat dalam mengikuti kegiatan pembelajaran (Muah, 2016). Keaktifan siswa membuat pembelajaran dapat berjalan sesuai dengan perencanan pembelajaran. Pembelajaran yang aktif mencakup kegiatan dimana siswa ikut terlibat didalamnya. Ini berarti siswa sedang melakukan sesuatu dan berpikir tentang apa yang mereka lakukan. Dalam lingkungan belajar aktif, siswa memegang kendali pembelajaran mereka, dan mereka telibat dalam pembelajaran tingkat tinggi, yaitu menganalisis, sintesis, dan evaluasi (Koohang, Paliszkiewicz, Goluchowski, \& Nord, 2016). Keaktifan peserta didik dalam pembelajaran akan mengakibatkan interaksi yang tinggi antara guru dengan siswa atau antara siswa dengan siswa itu sendiri (Effendi, 2013). Belajar aktif secara signifikan mampu meningkatkan keterampilan berfikir kritis siswa dalam kegiatan partisipasi kelas mereka seperti studi 
kasus, bermain game, debat kelas, aktivitas think-pair-share atau diskusi masalah kehidupan nyata (Hadibarata \& Rubiyanto, 2019). Siswa yang aktif adalah siswa yang menyusun pengetahuan mereka secara aktif, siswa merenungkan dan mengendalikan proses belajar mereka (Virtanen, Niemi, \& Nevgi, 2017). Ketika peserta didik aktif dalam kegiatan pembelajaran maka secara tidak langsung peserta didik tersebut terampil, dan seseorang yang terampil pasti kreaktif. Kreativitas sangat dibutuhkan oleh peserta didik dikarenakan peserta didik merupakan subjek yang harus mempersiapkan masa depan mereka sendiri, kreativitas dapat membantu peserta didik ketika mereka menemui permasalahan dalam kehidupan. Sehubungan dnegan pengembangan kreativitas harus diajarkan oleh pendidik pada tingkat satuan pendidikan. Alasan mendasar yang mengharuskan pengajaran kreativitas ini merupakan upaya dalam membantu peseta didik dalam mempersiapkan kemungkinan yang dihadapi di kemudian hari agar peserat didik memiliki alternative penyelesaian masalah yang tepat (Sugiarto \& Djukri, 2015). Apabila peserta didik telah memiliki kriteria tersebut berarti dalam pembelajara telah memnuhi 4 komponen yang arahkan pada pembelajaran abad 21.

Sehubungan dengan pentingnya sikap dan keaktifan belajar pada pembelajaran di abad 21 ini maka perlu dilakukan penelitian mengenai sikap dan keaktifan belajar untuk mengetahui korelasi sikap dan keaktifan belajar khususnya pada mata pelajaran IPA. Diharapkan hasilnya dapat dijadikan acuan untuk penelitian selanjutnya atau dapat menjadi pedoman bagi guru untuk mengukur sikap dan keaktifan belajar yang dimiliki siswa. Tujuan dari penelitian ini adalah mengetahui hubungan antara sikap dengan keaktifan belajar siswa terhadap mata pelajaran IPA.

\section{METODE}

Penelitian ini merupakan penelitian mix method dengan menggunakan desain explanatory. Pada penelitian ini menggunakan metode asosiatif jenis korelasional. Penelitian asosiatif adalah penelitian yang digunakan untuk mencari hubungan antara satu atau lebih variabel dependen dengan variabel independen (Suryani \& Hendryadi, 2015).

Penelitian ini dilaksanakan di Sekolah Menengah Pertama Negeri 18 Kota Jambi. Populasi dalam penelitian ini meliputi peserta didik kelas VII, VIII, dan IX SMPN 18 Kota Jambi. Sampel yang digunakan dalam penelitian ini berjumlah 147 siswa. Teknik pengambilan sampel dalam penelitian ini menggunakan cluster sampling. Cluster sampling (Area Sampling) digunakan untuk menentukan sampel bila obyek yang akan diteliti atau sumber data sangat luas, misalnya penduduk dari suatu negara, propinsi atau kabupaten (Sugiyono, 2017).

Dalam penelitian ini, peneliti menggunakan dua instrument kuesioner dimana, instumen sikap diadopsi dari penelitian (Astalini \& Kurniawan, 2019), dengan 56 butir pernyataan dan Cronbach Alpha sebesar 0,842 maka angket tersebut dikatakan reliable atau layak untuk digunakan. Angket sikap menggunakan skala likert lima. Untuk penyataan poitif Sangat Tidak Setuju memiliki skor 1, Tidak Setuju memiliki skor 2, Netral memiliki skor 3, Setuju memiliki skor 4, dan Sangat Setuju memiliki skor 5. Sebaliknya, untuk pernyataan negative Sangat Tidak Setuju memiliki skor 5, Tidak Setuju memiliki skor 4, Netral memiliki skor 3, Setuju memliki skor 2, dan Sangat Setuju memiliki skor 1. Instrumen ini menggunakan 7 indikator yang diadopsi dari TOSRA milik Fraser (1981) yaitu: Sikap terhadap penyelidikan IPA, Ketertarikan dalam belajar IPA, dan ketertarikan berkarir di bidang IPA. Selanjutnya untuk kuesioner keaktifan belajar peneliti adaptasi dari penelitian (Emosda \& Anggraini, 2018), yang terdiri dari 25 pernyataan. Angket keaktifan belajar ini juga menggunakan skala likert 5 yaitu Selalu (SL), Sering (SR), Kadang-Kadang (KK), Jarang (JR), dan Tidak Pernah (TP). Skor untuk jawaban dari pertanyaan positif adalah $\mathrm{SL}=5, \mathrm{SR}=4, \mathrm{KK}=3, \mathrm{JR}=2$, dan $\mathrm{TP}=1$.

Dalam pengumpulan data, kegiatan pertama yang harus dilakukan adalah memilih siswa berdasarkan kategori yang diberikan oleh peneliti, kemudian memberikan angket sikap dan angket kekatifan belajar kepada siswa, kemudian melakukan wawancara semi terstruktur untuk memastikan hasil kuantitatif yang telah dilakuakan. Kemudian data angket tersebut diolah dengan menggunakan aplikasi SPSS 25 untuk melihat statistik deskriptif, dalam bentuk mean, min, max, presentase, dan kategori siswa, sedangkan untuk data kualitatif menggunakan Miles \& Huberman yaitu reduksi data, penyajian data, dan penarikan kesimpulan (Milles \& Huberman, 1994).

Data yang dibutuhkan dalam penelitian dapat dikumpulkan atau diperoleh dari berbagi sumber data. Adapun prosedur pengumpulan data penelitian ini sesuai dengan diagram berikut: 
Jurnal Inovasi Pendidikan IPA, 6 (2), 2020 - 138

Maison Maison, Dwi Agus Kurniawan, Nur Ika Sani Pratiwi
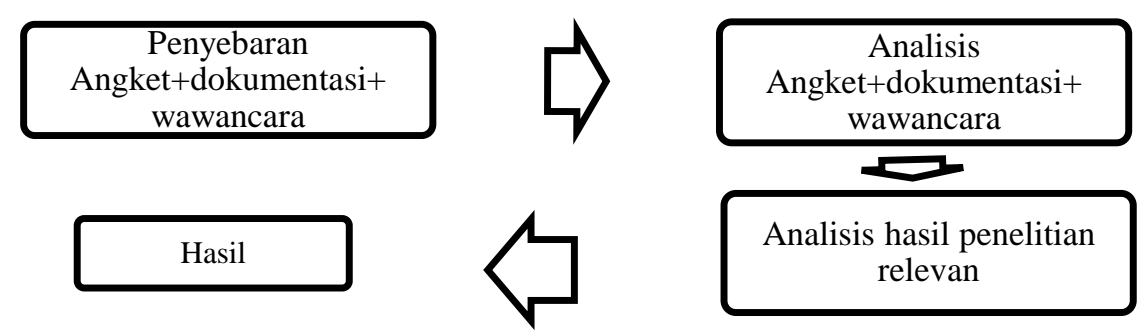

Dalam peneitian ini menggunakan analisis data kuantitatif dengan SPSS 25, untuk mencari statistic deskriptif dan statistic inferensial. Kemudian dilanjutkan dengan wawancara untuk memperkuat hasil data. Pada penelitian ini sebelum dilakukan uji Hipotesis terlebih dahulu dilakukan uji normalitas dan uji linearitas. Uji normalitas untuk mengetahui apakah data penelitian yang diperoleh berdistribusi normal atau tidak. Alat yang digunakan adalah model One Sample Kolmogorov-Smirnov. Hal ini bertujuan untuk memperkecil tingkat kesalahan baku dan mengetahui apakah data yang digunakan berdistribusi normal atau tidak. Dengan kriteria pengambilan keputusan: jika nilai Asymp Sig (2-tailed) $>0,05$ maka data berdistribusi normal. Uji linearitas untuk mengetahui apakah data penelitian yang diperoleh tersebut linear atau tidak, kriteria pengambilan keputusan jika nilai Sig > 0,05 maka data tersebut linear. Selanjutnya dilakukan pengujian hipotesis untuk mengetahui hubungan antara sikap dan keaktifan blajar siswa terhadap mata pelajaran IPA. Dalam hal ini peneliti menggunakan uji korelasi Parametrik dengan bantuan program komputer SPSS 25 dengan kriteria pengambilan keputusan jika Sig $>0,05$ maka Ho diterima dan Ha ditolak dan jika Sig < 0,05 maka Ho ditolak dan Ha diterima.

\section{HASIL DAN PEMBAHASAN}

Adapun hasil dari penelitian ini disajikan dalam tabel dibawah ini:

\section{Sikap terhadap penyelidikan IPA}

Pada indikator Sikap terhadap penyelidikan IPA dapat kita lihat hasilnya dari angket yang telah disebarkan, dengan hasil seperti Tabel 1.

Tabel 1. Sikap Terhadap Penyelidikan IPA

\begin{tabular}{|c|c|c|c|c|c|c|}
\hline \multicolumn{3}{|c|}{ Klasifikasi } & \multirow[t]{2}{*}{$\%$} & \multirow[t]{2}{*}{ Mean } & \multirow[t]{2}{*}{ Min } & \multirow[t]{2}{*}{ Max } \\
\hline Rentang & Sikap & Frek & & & & \\
\hline $7,00-12,60$ & Sangat tidak baik & 0 & 0,0 & 22,53 & 17,00 & 29,00 \\
\hline $12,70-18,20$ & Tidak baik & 10 & 6,8 & & & \\
\hline $18,30-23,80$ & Cukup & 54 & 36,7 & & & \\
\hline $23,90-29,40$ & Baik & 83 & 56,5 & & & \\
\hline $29,50-35,00$ & Sangat baik & 0 & 0,0 & & & \\
\hline
\end{tabular}

Berdasarkan Tabel 2, sikap siswa SMPN 18 Kota Jambi dominan berada pada kategori baik dengan perolehan data sebesar 56,5\% (83 dari 147) siswa, dengan skor maksimum yang diraih yaitu 29 dan skor minimum 17. Hal ini menunjukkan bahwa umumnya siswa sudah bersikap baik terhadap penyelidikan dalam IPA. Hasil penelitian juga memperoleh 6,8\% (10 dari 147) siswa di SMPN 18 Kota Jambi memiliki sikap yang tidak baik terhadap penyelidikan ilmiah. Hal ini dapat terjadi karena siswa tidak suka melakukan kegiatan eksperimen karena malas dan dianggap merepotkan. Selanjutnya 36,7\% (54 dari 147) siswa berada pada kategori cukup. Kemudian diperoleh nilai rata-rata sebesar 22,53.

\section{Ketertarikan memperbanyak waktu belajar IPA}

Pada indikator ketertarikan memperbanyak waktu belajar IPA dapat kita lihat hasilnya dari angket yang telah disebarkan, dengan hasil seperti Tabel 2. Berdasarkan Tabel 2, menunjukkan bahwa sikap siswa SMPN 18 Kota Jambi pada indicator ketertarikan memperbanyak waku belajar IPA dominan berada pada kategori cukup dengan perolehan data yaitu sebesar 70,7\% (104 dari 147) siswa, dengan skor maksimum yang diraih yaitu 37 dan skor minimum 19. Hal ini menunjukkan bahwa umumnya siswa masih bingung untuk memperbanyak waktu belajar IPA. Hasil penelitian juga menunjukkan sebanyak 27,9\% (41 dari 147) siswa memiliki sikap yang baik terhadap indikator memperbanyak waktu belajar 
IPA. Kemudian, sebanyak 0,7\% (1 dari 147) siswa mempunyai sikap yang tidak baik, dan sebanyak 0,7\% (1 dari 147) siswa mempunyai sikap yang sangat tidak baik. Hal ini menunjukkan bahwa ada beberapa siswa yang mempunyai sikap negatif terhadap IPA yang dapat dilihat dari data yang menunjukkan ada siswa yang tidak ingin memperbanyak waktu belajar IPA. Kemudian diperoleh nilai rata-rata sebesar 25,97 .

Tabel 2. Ketertarikan Memperbanyak Waktu Belajar IPA

\begin{tabular}{|c|c|c|c|c|c|c|}
\hline \multicolumn{3}{|c|}{ Klasifikasi } & \multirow{2}{*}{$\%$} & \multirow{2}{*}{ Mean } & \multirow{2}{*}{ Min } & \multirow{2}{*}{$\operatorname{Max}$} \\
\hline Rentang & Sikap & Frek & & & & \\
\hline $8,00-14,40$ & Sangat tidak baik & 1 & 0,7 & \multirow{5}{*}{25,97} & \multirow{5}{*}{19,00} & \multirow{5}{*}{37,00} \\
\hline $14,50-20,80$ & Tidak baik & 1 & 0,7 & & & \\
\hline $20,90-27,20$ & Cukup & 104 & 70,7 & & & \\
\hline $27,30-33,60$ & Baik & 41 & 27,9 & & & \\
\hline $33,70-40,00$ & Sangat baik & 0 & 0,0 & & & \\
\hline
\end{tabular}

\section{Adopsi dari Sikap Ilmiah}

Pada indikator Adopsi Sikap Ilmiah dapat kita lihat hasilnya dari angket yang telah disebarkan, dengan hasil seperti Tabel 3

Tabel 3. Adopsi Dari Sikap Ilmiah

\begin{tabular}{|c|c|c|c|c|c|c|c|}
\hline \multicolumn{3}{|c|}{ Klasifikasi } & \multirow[b]{2}{*}{$\%$} & \multirow[b]{2}{*}{ Mean } & \multirow[b]{2}{*}{ Median } & \multirow[b]{2}{*}{ Min } & \multirow[b]{2}{*}{$\operatorname{Max}$} \\
\hline Rentang & Sikap & Frek & & & & & \\
\hline $7,00-12,60$ & Sangat tidak baik & 0 & 0,0 & \multirow{5}{*}{22,27} & \multirow{5}{*}{22,00} & \multirow{5}{*}{15,00} & \multirow{5}{*}{30,00} \\
\hline $12,70-18,20$ & Tidak baik & 12 & 8,2 & & & & \\
\hline $18,30-23,80$ & Cukup & 94 & 63,9 & & & & \\
\hline $23,90-29,40$ & Baik & 39 & 26,5 & & & & \\
\hline $29,50-35,00$ & Sangat baik & 2 & 1,4 & & & & \\
\hline
\end{tabular}

Berdasarkan Tabel 3, menunjukkan bahwa sebanyak 63,9\% (94 dari 147) siswa berkategori cukup dengan skor maksimal dari keseluruhan pernyataan adalah 30, skor minimal 15, dan nilai rata-rata 22,27. Hal ini menunjukkan bahwa siswa masih bingung tentang bagaimana berfikir secara ilmiah atau bersikap ilmiah dalam pembelajaran IPA. Selanjutnya, sebanyak 26,5\% (39 dari 147) siswa berkategori baik. Hal ini menunjukkan bahwa sebagian siswa sudah mengakui tentang adanya sikap ilmiah dalam pembelajaran sains/IPA. Kemudian, 1,4 \% (2 dari 147) berkategori sangat baik. Hal ini menunjukkan ada siswa yang mampu berfikir secara ilmiah dan bersikap ilmiah dengan baik. Serta 8,2\% (12 dari 147) berkategori tidak baik, hal ini menunjukkan bahwa ada siswa yang tidak mempunyai kriteria sikap ilmiah dalam pemebelajaran IPA.

\section{Rasa Ingin Tahu yang Tinggi}

Pada indikator rasa ingin tahu yang tinggi dapat kita lihat hasilnya dari angket yang telah disebarkan, dengan hasil seperti Tabel 4.

Tabel 4. Rasa Ingin Tahu Yang Tinggi

\begin{tabular}{|c|c|c|c|c|c|c|}
\hline \multicolumn{3}{|c|}{ Klasifikasi } & \multirow{2}{*}{$\%$} & \multirow{2}{*}{ Mean } & \multirow{2}{*}{ Min } & \multirow{2}{*}{$\operatorname{Max}$} \\
\hline Rentang & Sikap & Frek & & & & \\
\hline $5.0-9.0$ & Sangat tidak baik & 1 & 0.7 & & & \\
\hline $9.1-13.0$ & Tidak baik & 35 & 23.8 & & & \\
\hline $13.1-17.0$ & Cukup & 45 & 30.6 & 16.1 & 7.0 & 25 \\
\hline $17.1-21.0$ & Baik & 61 & 41.5 & & & \\
\hline $21.1-25.0$ & Sangat Baik & 5 & 3.4 & & & \\
\hline
\end{tabular}

Berdasarkan Tabel 4, tercatat bahwa sebanyak 41,5\% (671dari 147) siswa dominan berkategori baik dengan skor maksimal dari keseluruhan pernyataan di indikator rasa ingin tahu yang tinggi adalah 25. Selanjutnya sebesar 3,4\% (5 dari 147) siswa berkateggori sangat baik. Kemudian ada sebanyak $30,6 \%$ (45 dari 147) siswa berkategori cukup yang berarti siswa masih bingung mengenai adanya peran IPA dalam kehidupan sehari-hari. Sedangkan sebanyak 23,8\% (35 dari 147) siswa berkategori tidak baik, dan 0,7\% (1 dari 147) siswa berkategori sangat tidak baik, hal ini menunjukkan siswa menganggap 
mempelajari IPA bukanlah hal yang terlau penting. Kemudian diperoleh nilai rata-rata sebesar 16,1 dan skor minimum 7.

\section{Pantang Menyerah}

Pada indikator pantang menyerah dapat kita lihat hasilnya dari angket yang telah disebarkan, dengan hasil seperti Tabel 6 .

Tabel 6. Pantang Menyerah

\begin{tabular}{|c|c|c|c|c|c|c|}
\hline \multicolumn{3}{|c|}{ Klasifikasi } & \multirow{2}{*}{$\%$} & \multirow{2}{*}{ Mean } & \multirow{2}{*}{ Min } & \multirow{2}{*}{$\operatorname{Max}$} \\
\hline Rentang & Sikap & Frek & & & & \\
\hline $4.0-7.2$ & Sangat tidak baik & 5 & 3.4 & & & \\
\hline $7.3-10.4$ & Tidak baik & 17 & 11.6 & & & \\
\hline $10.5-13.6$ & Cukup & 67 & 45.6 & 12.9 & 7.0 & 19.0 \\
\hline $13.7-16.8$ & Baik & 48 & 32.7 & & & \\
\hline $16.9-20.0$ & Sangat Baik & 10 & 6.8 & & & \\
\hline
\end{tabular}

Berdasarkan Tabel 6, dapat dideskripsikan bahwa keaktifan belajar siswa SMPN 18 Kota Jambi untuk indicator pantang menyerah berada pada kategori cukup baik dengan perolehan data sebesar 45,6\% (67 dari 147). Selanjutnya 32,7\% (48 dari 147) siswa berdasarkan analisis data termasuk dalam kategori baik. Selanjutnya 6,8\% (10 dari 147) siswa berada pada kategori sangat baik. Hal ini berarti ada sebagain siswa yang sudah paham tentang pentingnya IPA, sehingga mereka memunyai sikap yang pantang menyerah terhadap pembelajaran IPA. Sedangkan sebanyak 11,6\% (17 dari 147) siswa berada pada kategori tidak baik, kemudian sebanyak 3,4\% (5 dari 147) siswa berada pada kategori sangat tidak baik. Kemudian diperoleh nilai rata-rata sebesar 12,9, median 13, minimum 7, dan maksimum 19.

\section{Ingin Mencari Pengalaman-Pengalaman Baru}

Pada indikator ingin mencari pengalaman-pengalaman baru dapat kita lihat hasilnya dari angket yang telah disebarkan, dengan hasil seperti Tabel 7.

Tabel 7. Ingin Mencari Pengalaman-Pengalaman Baru

\begin{tabular}{|c|c|c|c|c|c|c|}
\hline \multicolumn{3}{|c|}{ Klasifikasi } & \multirow{2}{*}{$\%$} & \multirow{2}{*}{ Mean } & \multirow{2}{*}{ Min } & \multirow{2}{*}{ Max } \\
\hline Rentang & Sikap & Frek & & & & \\
\hline $8.0-14.4$ & Sangat tidak baik & 0 & 0 & & & \\
\hline $14.5-20.8$ & Tidak baik & 9 & 6.1 & & & \\
\hline $20.9-27.2$ & Cukup & 57 & 38.8 & 28.3 & 18.0 & 37.0 \\
\hline $27.3-33.6$ & Baik & 62 & 42.2 & & & \\
\hline $33.7-40.0$ & Sangat Baik & 19 & 12.9 & & & \\
\hline
\end{tabular}

Berdasarkan Tabel 7, dapat dideskripsikan bahwa keaktifan belajar siswa SMPN 18 kota Jambi pada indicator ingin mencari pengalaman-pengalaman baru dominan berada pada kategori baik dengan perolehan data yaitu sebesar $42,2 \%$ (82 dari 147) siswa, dengan skor maksimalnya yaitu 37 . Selanjutnya sebesar 12,9\% (19 dari 147) siswa berada pada kategori sangat baik. Kemudian 38,8\% (57 dari 147) siswa berdasarkan analisis data termasuk dalam kategori cukup. Sedangkan sebanyak 6,1\% (9 dari 147) siswa berkategori tidak baik, dan hal ini menunjukkan bahwa siswa tidak mengerti tentang pentingnya belajar IPA dengan aktif, hal ini ditunjukkan dari siswa tidak mau mencari pengalaman baru dalam belajar IPA dan hanya mengandalkan materi yang diberikan oleh guru saja. Didapatkan pula skor ratarata dari penelitian ini yaitu 28,3, dan skor maksimum 18 .

\section{Analisa Korelasi Sikap dengan Keaktifan Belajar}

Adapun hasil analsisi korelasi antara sikap dengan keaktifan belajar siswa pada mata pelajaran IPA dapat ditunjukkan pda Tabel 8.

Korelasi digunakan untuk menentukan seberapa kuat hubungan antara variabel bebas dengan variabel terikat. Dalam penelitian ini menggunakan taraf signifikasi 5\%. Berdasarkan data hasil uji Correlations atau uji hubungan dengan menggunakan SPSS.25 dari tabel Correlation Pearson dapat diketahui bahwa nilai signifikansi sebesar 0,046. Nilai ini menunjukkan bahwa nilai sig $<\alpha=0,046<$ 0,05, maka Ho ditolak atau dapat dikatakan terdapat hubungan antara sikap dengan keaktifan belajar siswa pada mata pelajaran IPA di SMPN 18 Kota Jambi. 
Jurnal Inovasi Pendidikan IPA, 6 (2), 2020 - 141

Maison Maison, Dwi Agus Kurniawan, Nur Ika Sani Pratiwi

Tabel 8. Hasil Uji Korelasi

\begin{tabular}{cccc}
\hline \multicolumn{2}{c}{ Sikap } & \multicolumn{2}{c}{ Keaktifan belajar } \\
\hline Pearson Correlation & Sig. (2-tailed) & Pearson Correlation & Sig. (2-tailed) \\
\hline $.165^{*}$ & .046 & $.165^{*}$ & .046 \\
\hline
\end{tabular}

Hasil wawancara untuk indikator sikap terhadap penyelidikan IPA siswa mengatakan bahwa menyukai kegiatan praktikum, karena dengan melakukan praktikum atau percobaan materi yang dijelaskan menjadi lebih mudah untuk dipahami dan kegiatan pembelajaran menjadi lebih menyenangkan. Selanjutnya wawancara dengan siswa untuk indicator ketertarikan memperbanyak waktu belajar IPA, siswa yang berada pada kategori tidak baik mengatakan bahwa mereka lebih suka menggunakan waktu luangnya untuk melakukan hal lain dibandingkan membaca buku tentang IPA untuk menambah pengetahuan mereka. Sedangkan siswa yang menjawab dengan kategori baik mengatakan bahwa mereka ingin manambah waktu belajar IPA, karena IPA merupakan mata pelajaran yang menyenangkan dan tidak membosankan. Selanjutnya dilakukan wawancara untuk indicator adopsi sikap ilmiah sebagian siswa mengatakan kurang menyukai mata pelajaran IPA sehingga mereka tidak menerapkan sikap-sikap ilmiah selama melakukan percobaan. Apabila siswa mempunyai sikap ilmiah dalam pembelajaran, siswa akan dapat menyelesaikan permasalahan-permasalahan dalam IPA maupun permasalahan yang ada disekitarnya dengan bersikap secara ilmiah atau berpola pikir secara kritis, logis dan terstruktur. Selanjutnya peneliti melaukan wawancara untuk variabel keaktifan belajar, dimana beberapa siswa sudah aktif dalam mengikuti pembelajaran IPA tetapi masih ada yang pasif atau terlihat bosan dan mengantuk saat pembelajara berlangsung. Siswa yang aktif mengatakan bahwa ia senang belajar IPA sedangkan siswa yang pasif mengatakan bahwa ia tidak menyukai pelajaran IPA sehingga membuat mereka malas untuk belajar.

Analisis korelasi menunjukkan bahwa ada signifikansi korelasi yang positif antara sikap siswa, dan keaktifan belajar siswa $(<0,05)$. Ilmu Pengetahuan Alam adalah bagian dari sains yang terbentuk dari konsep, fakta, teori, prinsip, hipotesis, dan model yang merupakan tubuh dari pengetahuan dari rasa ingin tahu seseorang (Sari, Erika, \& Neldawati, 2020). Konsep belajar IPA pada hekekatnya banya diaplikasikan dalam kehidupan sehari-hari. Dengan belajar IPA akan memeberikan bekal untuk memecahkan permasalahan kehidupan sehari-hari (Widiadnyana, Sadia, \& Suastra, 2014). Analisis ilmiah sangat penting bagi siswa hal ini terkait dengan peran ilmu pengetahuan untuk memecahakan masalah dalam sains (Wati, Mahtari, Hartini, \& Amalia, 2019). Siswa yang mncoba mengulang artinya siswa tersebut suka akan penyelidikan terhadap IPA. Percobaan pada IPA harus dilandasi kejujuran dan tiidak boleh memanipulasi data (Sayekti, 2015). Pada eksperimen siswa akan mengambil data, beberapa siswa mungkin akan mengalami kegagalan. This is because scientific attitudes can shape students' thinking creatively and critically (Syahrial, Asrial, Kurniawan, Pratama, \& Perdana, 2019). Siswa ditekankan pada pemberian pengalaman secara langsung dan juga berdasarkan pada sains, lingkungan, teknologi, dan masyarakat (Afrizon, Ratnawulan, \& Fauzi, 2012). Menurut (Hamdu \& Agustina, 2011), dengan memberikan motivasi kepada siswa maka siswa akan tergerak, terarahkan sikap dan perilakunya untuk meluangkan waktu belajar IPA. Minat berperan penting pada kehidupan siswa untuk masa depannya (Riwahyudin, 2015). Siswa yang berminat berlajar IPA akan memperbanyak waktu belajar IPA dan tertarik berkarir dibidang IPA. Seperti yang telah dipaparkan di pendahuluan, sikap siswa terhadap pembelajaran terdiri dari sikap positif dan juga sikap negatif. Sangat penting untuk mengembangkan sikap positif siswa terhadap pelajaran sains. Sikap positif siswa terhadap sains akan melibatkan sains sebagai objek yang menarik. Jika siswa memiliki sikap negatif terhadap sains, mereka juga tidak akan menyukai mata pelajaran IPA ataupun guru IPAnya (Guido, 2013). Sikap positif ataupun negatif yang dimiliki siswa dapat mempengaruhi pembelajaran dalam sains.

Saat siswa menyukai pelajar IPA akan membuat siswa aktif dan antusias selama pembelajaran berlangsung. Keaktifan belajar dilihat saat siswa antusias menjawab pertanyaan-pertanyaan dari guru, mengerjakan tugas yang diberikan guru dan saat guru bertanya siswa menanggapi pertanyaan guru tersebut (Nuryasintia \& Wibowo, 2019). Keaktifan belajar siswa dapat terlihat dari keterlibatan siswa dalam proses belajar yang beragam seperti ketika mendengarkan penjelasan guru, diskusi, melaporkan implementasi tugas dan sebagainya (Winarso, 2016). Siswa yang aktif dalam pembelajaran akan lebih semangat dan percaya diri untuk mengungkapkan pendapatnya. Siswa yang aktif dalam belajar mempunyai percaya diri yang tinggi dalam pembelajaran (Kara, 2009). Kepercayaan diri peserta didik akan kemampuan mereka dalam menyelesaikan permasalahan dan mempelajari ilmu alam akan sangat 
menentukan keterlibatan peserta didik dalam penyelidikan (Stefan \& Cimos, 2010). Keaktifan siswa membuat pembelajaran berjalan sesuai dengan perencanaan pembelajaraan yang sudah disusun oleh guru (Wibowo, 2016). Untuk membuat siswa aktif dalam pembelajaran bisa dilakukan dengan cara memberi pertanyaan yang diberikan oleh guru (Sumilia, Puspita, \& Elfrida, 2019). Siswa yang termotivasi dalam belajar tidak akan mudah menyerah ketika mendapat tantangan (Tasign \& Coskun, 2018). Dalam proses pembelajaran IPA biasanya siswa lebih memilih untuk melakukan eksperimen atau percobaan daripada bertanya kepada guru ketika ingin mengetahui suatu materi IPA, karena IPA akan jauh lebih mudah untuk dipahami ketika dipraktikan secara langsung oleh karena itu siswa harus aktif dalam belajar IPA.

Implementasi kurikulum 2013 disertai dengan adanya perubahan paradigma pembelajaran, yaitu (1) pembelajaran yang berpusat kepada guru berubah menjadi berpusat pada siswa; (2) guru sebagai satu-satunya sumber belajar berubah menjadi siswa belajar dengan menggunakan multi sumber; (3) siswa diberi tahu berubah mencari tahu; (4) pembelajaran yang menerapkan Low Order Thingking Skill (LOTS) berubah menjadi Higher Order Thingking Skills (HOTS) dalam rangka memberikan keterampilan abad 21 kepada siswa atau 4C (Communication, Collaboration, Critical Thingking and problem solving, dan creative and innovation) melalui penerapan pendekatn saintifika yang meliputi $5 \mathrm{M}$ (mengamati, menanya, mengumpulkan informasi, menalar/mengasosiasi, dan mengomunikasikan).

Implementasi kurikulum 2013 sangat menekankan belajar aktif karena selama ini memang tidak dapat dipungkiri bahwa pembelajaran di kelas banyak yang kurang aktif. Peran guru sangat dominan, siswa pasif. Hanya duduk, diam, dengar, dan catat. Dalam menerapkan pembelajaran aktif, peran guru bukan sebagai satu-satunya sumber belajar, tetapi menjdai salah satu sumber belajar. Guru harus menguasai multimodel dan multimetoda pembelajaran, menjembatani dan mengeksplorasi kemampuan yang beragam tersebut. Hal ini sesuai yang diungkapkan oleh (Asrial, Syahrial, Kurniawan, Subandiyo, \& Amalina, 2019); (Putri \& Jumadi, 2017), bahwa cara mengajar guru cukup berpengaruh terhadap minat dan hasil belajar siswa untuk mempelajari suatu mata pelajaran tertentu. Oleh karena itu, guru dalam mengajar hendaknya memperhatikan gaya belajar atau learning style siswa, yaitu bagaimana cara siswa bereaksi dan menggunakan stimulus-stimulus yang diterima dalam proses pembelajaran (Rijal \& Bachtiar, 2015). Dengan Adanya metode pembelajaran guru yang bervariasi, perhatian guru terhadap seluruh siswa, motivasi dari guru, cara penyampaian materi dari guru, media pembelajaran yang digunakan guru, dan sikap guru terhadap seluruh siswa menjadi faktor pendukung keaktifan belajar siswa (Maradona, 2016).

UNESCO menekankan 4 (empat) pilar belajar, yaitu (1) belajar untuk tahu (learning to know); (2) belajar untuk melakukan (learning to do); (3) belajar utuk menjadi (learning to be); (4) belajar untuk hidup bersama (learning to live together). Keempat pilar pendidikan tersebut hanya bisa dibangun melalui pembelajaran yang aktif. Bahkan beberapa penelitian telah merekomendasikan pentingnya Pembelajaran Aktif, Kreatif, Efektif, dan Menyenangkan (PAKEM). Secara administratif, skenario pembelajaran aktif berbasis keterampilan abad 21 ditulis dalam Rencana Pelasanaan Pembelajaran (RPP). Mulai dari merumuskan indikator pencapaian kompetensi, tujuan pembelajaran, penggunaan model atau metode pembelajaran, dan tahapan kegiatan pembelajaran (kegiatan pendahuluan, inti, dan penutup). Selain itu, dalam proses penilaian pun perlu menenkankan ketercapaian hasil belajar aktif. Disamping penilaian pengetahuan (kognitif) dan keterampilan (psikomotor) juga perlu penilaian sikap delama diskusi atau kerja kelompok melalui jurnal atau lembar observasi.

Kedua variabel ini yaitu sikap terhadap pelajaran IPA, dan keaktifan belajar saling berhubungan. Sikap siswa yang positif akan membuat siswa akan aktif dan antusias dalam belajar. Sedangkan sikap negatif siswa akan membuat siswa pasif dalam belajar. Hasil ini sesuai dengan penelitian yang dilakukan oleh (Ratnawati \& Marimin, 2014), menyatakan bahwa terdapat pengaruh antara sikap dan keaktifan belajar. Artinya, apabila siswa mempunyai sikap yang negatif terhadap mata pelajaran maka siswa akan menjadi malas dan tidak aktif dalam pembelajaran. Sebaliknya, siswa yang mempunyai sikap positif terhadap pembelajaran akan menjadikan siswa aktif dalam mengikuti kegiatan pembelajaran.

\section{SIMPULAN}

Berdasarkan hasil penelitian yang telah dilakukan, maka dapat diperoleh kesimpulan bahwa terdapat hubungan yang signifikan antara sikap dengan keaktifan belajar siswa pada mata pelajaran IPA 
di SMPN 18 Kota Jambi setelah dilakukan uji hipotesis korelasi pearson dengan nilai signifikansi 0.046 $<0.05$ maka dpat dinyatakan bahwa Ho ditolak.

\section{DAFTAR PUSTAKA}

Adeyemo, S. A., \& Babajide, V. T. (2012). The Influence of Social and Economic Disadvantage on Students' Academic Achievemnet in Senior Secondary School Physics. International Journal of educational Research and Technology (IJERT), 3(2), 1-10.

Afrizon, R., Ratnawulan, \& Fauzi, A. (2012). Peningkatan Perilaku Berkarakter dan Keterampilan Berpikir Kritis Siswa Kelas IX MTSN Model Padang Pada Mata Pelajaran IPA-Fisika Menggunakan Model Problem Based Instruction. Jurnal Penelitian Pembelajaran Fisika, 1(1), $1-16$.

Asrial, Syahrial, Kurniawan, D. A., Subandiyo, M., \& Amalina, N. (2019). Analisis Kompetensi Pedagogik dan Kompetensi IPA Terhadap Calon Guru Sekolah dasar PGSD FKIP Universitas Jambi. Jurnal DIDIKA: Wahana Ilmiah Pendidikan Dasar, 4(2), 41-49.

Astalini, \& Kurniawan, D. A. (2019). Pengembangan Instrumen Sikap Siswa Sekolah Menengah Pertama Terhadap Mata Pelajaran IPA. Jurnal Pendidikan Sains, 7(1), 1-7.

Astalini, \& Kurniawan, D. A. (2019). Pengembangan Instrumen Sikap Siswa Sekolah Menengah Pertama Terhadap Mata Pelajaran IPA. Jurnal Pendidikan Sains, 7(1), 1-7.

Astalini, Kurniawan, D. A., Melsayanti, R., \& Destilanti, A. (2018). Sikap Terhadap Mata Pelajaran IPA Se-Kabuoaten Muaro Jambi. Lentera Pendidikan, 7(1), 214-227.

Astalini, Pathoni, h., Kurniawan, D. A., \& Kurniawan, N. (2019). The Correlation Between Attitudes And Decipline Toward Science Of Secondary School. Jurnal Pendidikan Sains, 7(1), 9-14.

Astuti, T. P. (2019). Model Problem Based Learning Dengan Mind Mapping Dalam Pembelajaran IPA Abad 21. Proceeding of Biology Education, 3(1), 64-73.

Effendi, M. (2013). Integrasi Pembelajaran Active Learning dan Internet-Based Learning Dalam Meningkatkan Keaktifan dan Kreativitas Belajar. Nadwa, Jurnal Penelitian Islam, 7(2), 1-27.

Emosda, \& Anggraini, E. P. (2018). Hubungan Gaya Mengajar Guru Dengan Keaktifan Belajar Siswa Sekolah Dasar. Jurnal Gentala, 3(1), 93-110.

Etherington, M. (2011). Investigative Primary Science: A Problem-Based Learning Approach. Australian Journal of Teacher education, 36(9). doi:http://Dx.Doi.org/10.14221/Ajte.2011v36n9.2

Guido, R. M. (2013). Attitude and Motivation Towards Learning Physics. International Journal of Engineering Research \& Technology (IJERT), 2(11).

Hadibarata, T., \& Rubiyanto, R. (2019). Active Learning Strategies in Environmental Engineering Course: A Case Study In Curtin University Malaysia. Jurnal Pendidikan IPA Indonesia, 8(4), 456-463.

Hamdu, G., \& Agustina, L. (2011). Pengaruh Motivasi Belajar Siswa Terhadap Prestasi Belajar IPA di Sekolah Dasar. Jurnal Penelitian Pendidikan, 12(1), 81-86.

Huang, L. J., Abdullah, F. A., \& Bunyamin, M. A. (2013). Aplikasi Konsep Fizik Dalam Menyelesaikan Masalah Yang Berasaskan STEM Bagi Pelajar Tingkatan Enam Atas. International Seminar on Quality and Affordable education (ISQAE).

Indriati, D. (2012). Meningkatkan Hasil Belajar IPA Konsep Cahaya Melalui Pembelajaran ScienceEdutaiment Berbantuan Media Animasi. Jurnal Pendidikan IPA Indonesia, 1(2), 192-197.

Kara, A. (2009). The effect of a Learning Theories' Unit on Students' Attitudes Toward Learning. Australian Journal of Teacher Education, 34(1). doi:http://dx.doi.org/10.14221/ajte.2009v34n3.5

Koohang, A., Paliszkiewicz, J., Goluchowski, J., \& Nord, J. H. (2016). Active Learning For Knowledge Construction In E_Learning: A Replication Study. Journal of Computer Information System, 56(3), 238-243.

Kurniawan, D. A., Astalini, \& Anggraini, L. (2018). Evaluasi sikap siswa SMP terhadap IPA di Kabupaten Muaro Jambi. Jurnal Ilmiah DIDAKTIKA, 19(1), 124-139. 
Kurniawan, D. A., Astalini, Darmaji, \& Melsayanti, R. (2019). Students' Attitude Toward Natural Sciences. International Journal of Evaluation and Research and Education (IJERE), 8(3), 445460.

Lin, J., Cheng, M., Chang, Y. C., \& Li, H. (2014). Construct Evaluation Of Student Attitudes Towards Science. EURASIA Journal of Mathematics, Science and Technology Education, 10(5), 415-426.

Maradona. (2016). Faktor-Faktor Yang Mempengaruhi Keaktifan Belajar Siswa Kelas IVB SD. Jurnal Pendidikan Guru Sekolah Dasar, 17(5), 1619-1628.

Milles, M. B., \& Huberman, A. M. (1994). Qualitative Data Analysis (2nd ed). SAGE: Thousand Oaks, CA.

Muah, T. (2016). Penggunaan Model Pembelajaran Problem based Instruction (PBI) Untuk Meningkatkan Keaktifan dan Hasil Belajar Matematika Siswa Kelas 9B Semester Gasal tahun Pelajaran 2014/2015. Scholaria, 6(1), 41-53.

Nuryasintia, I., \& Wibowo, L. A. (2019). Learning Activeness Through Learning Media and Class Management. Advances in Economics, Business and Management Research, 65, 145-148.

Ong, K. J., Chou, Y. C., Yang, D. Y., \& Lin, C. C. (2020). Creative Drama In Science Education: The Effects On Situational Interest, Career Interest, And Science-Related Attitudes Of Science Majors And Non-Science Majors. EURASIA Journal of Mathematics, Science and Technology Education, 16(4), 1-18.

Purbosari, P. M. (2016). Pembelajaran Berbasis Proyek Mebuat Ensiklopedia Ilmu Pengetahuan Alam (IPA) Untuk Meningkatkan Academic Skill Pada Mahasiswa. Scholaria, 6(3), 231-238.

Putri, R. F., \& Jumadi, J. (2017). Kemampuan Guru Fisika Dalam Menerapkan Model-Model Pembelajaran Pada Kurikulum 2013 Serta Kendala-Kendala yang Dihadapi. Jurnal Inovasi Pendidikan IPA, 3(2), 201-211.

Ratnawati, A., \& Marimin. (2014). Pengaruh Kesiapan belajar, Minat Belajar, Motivasi Belajar, dan Sikap Siswa Terhadap Keaktifan Belajar Siswa Jurusan Administrasi Perkantoran Pada Diklat Produktif AP di SMK Negeri 2 Semarang. Economic Education Analysis Journal, 3(1), 77-82.

Redhana, I. W. (2019). Mengembangkan Keterampilan Abad Ke-21 Dalam Pembelajaran Kimia. Jurnal Inovasi Pendidikan Kimia, 13(1), 2239-2253.

Rijal, S., \& Bachtiar, S. (2015). Hubungan Antara Sikap, Kemandirian Belajar, dan Gaya Belajar Dengan Hasil Belajar Kognitif Siswa. Jurnal Bioedukatika, 3(2), 15-20.

Riwahyudin, A. (2015). Sikap Siswa dan Minat Belajar Siswa Terhadap Hasil Belajar IPA Siswa Kelas V Sekolah Dasar di Kabupaten Lamandau. Jurnal Pendidikan Dasar, 6(1), 11-23.

Sari, N., Erika, E., \& Neldawati, N. (2020). Student Attitudes Towards Natural Science: Review of Pleasures and Career Interests At Junior High School 17 Jambi City. International Journal of Indonesian Education and Teaching, 4(1), 102-109. doi:https://doi.org/10.24071/ijiet.2020.040408

Sayekti, I. C. (2015). Peran Pembelajaran IPA di Sekolah Dalam Membangun Karakter Anak. Prosiding Seminar Nasiona dan Call for Papers, 140-146.

Schwab, K. (2016). The Fourth Industrial Revolution. Switzerland, World Economic Forum.

Stefan, M., \& Cimos, F. (2010). The 8th and 9th Grades Students' Attitude Towards Teaching and Learning Physics. Acta Didactica Napocensia, 2(1), 7-14.

Sudarisman, S. (2015). Memahami Hakikat Dan Karakteristik Pembelajaran Biologi Dalam Upaya Menjawab Tantangan Abad 21 Serta Optimalisasi Implementasi Kurikulum 2013. Jurnal Florea, 2(1), 29-35.

Sugiarto, A., \& Djukri. (2015). Pembelajaran Berbasis SETS Sebagai Upaya Meningkatkan Kreativitas Dalam Pemecahan Masalah Pencemaran Lingkungan. Jurnal Inovasi Pendidikan IPA, 1(1), 1-11.

Sugiyono. (2017). Metode Penelitian Pendidikan Pendekatan Kuantitatif, Kualitatif, dan R\&D. Bandung: Alfabeta.

Sumilia, E., Puspita, H., \& Elfrida. (2019). Students' Responses Toward Teachers' Bengkulu. Journal of Aplied Linguistics and Literacy, 3(2), 108-121. 
Suryani, \& Hendryadi. (2015). Metode Riset Kuantitatif: Teori dan Aplikasi Pada Penelitian Bidang Manajemen dan Ekonomi Islam. Jakarta: Kencana.

Syahrial, Asrial, Kurniawan, D. A., Pratama, R. A., \& Perdana, R. (2019). Towards Improving The Critical Thinking Skills of Pre-Service Teachers in Indonesia. Journal of education and Learning (Edulearn), 575-582.

Tasign, A., \& Coskun, G. (2018). The Relationship Between Academic Motivations and University Students' Attitudes Towards Learning. International Journal of Instruction, 11(4), 935-950. doi:https://doi.org/10.12973/iji.2018.11459a

USTA, E., \& AKKANAT, C. (2015). Investigating Scientific Creativity Level of Seventh Grade Students. Procedia Social and Behavioral Sciences, 19(1), 1408-1415.

Utaminingsih, R., Rahayu, A., \& Andini, D. W. (2018). Pengembangan RPP IPA Sekolah Dasar Berbasis Problem-Based Learning Untuk Siswa Learning Disabilitas. Jurnal Inovasi Pendidikan IPA, 4(1), 191-202.

Virtanen, P., Niemi, H., \& Nevgi, A. (2017). Active Learning and Self-Regulation Enhance Student Teachers Professional Competence. Australian Journal of Teacher Education, 42(12), 1-20.

Wati, M., Mahtari, S., Hartini, S., \& Amalia, H. (2019). A rasch Model Analysis on Junior High School Students' Scientific Reasoning Ability. iJIM, 13(7), 141-149. doi:https://doi.org/10.3992/ijim.v13i07.10760

Wibowo, N. (2016). Upaya Peningkatan Siswa Melalui Pembelajaran Berdasarkan Gaya Belajar di SMK Negeri 1 Saptosari. Jurnal Electronics, Informatics, and Vocational Education (ELINVO), l(2), 128-139.

Widiadnyana, I. W., Sadia, I. W., \& Suastra, I. W. (2014). Pengaruh Model Discovery Learning Terhadap Pemahaman Konsep IPA dan Sikap Ilmiah Siswa SMP. e-Journal Program Pascasarjana Pendidikan Ganesha, 4, 1-13.

Winarso, W. (2016). Assessing The Readiness of Student Learning Activity and Learning Outcome. Jurnal Pencerahan, 10(2), 74-88. 